\title{
WENDT'S BLINDSPOT: THE LIMITS OF THE (RE)CONSTRUCTION OF COLLECTIVE IDENTIY AND WHY THE SELF-HELP SYSTEM CANNOT BE OVERCOME
}

\author{
Getúlio Alves de Almeida Neto ${ }^{1}$
}

\begin{abstract}
The objective of this article is to identify the limits of Wendt's $(1992,1994)$ theory, in which he suggests the possibility of states to overcome the self-help system through a creation of collective identity. I too take the constructivist premise that identities and interests are socially constructed as a starting point, but I argue that the dimension of politics limits the scope for real altruistic interests of states. My hypothesis is that these limits rest neither on the international structure nor on human nature, but are a feature of political relations. However, this assumption does not mean co-operation is impossible or should not be pursued. I make use of Aristotelian and Kantian philosophy to support my argument that, through human beings' tendency to socialisation, they are also inclined to form political groups. I also analyse the Schmittian concept of the political, as defined by the antithesis friend-enemy, and the discussion made by Stoppino and Bobbio (1998) on politics and power. I shall conclude that as long collective identities form political entities, there will be the potentiality of a conflict which inhibits the creation of an international collective identity.
\end{abstract}

KEYWORDS: Constructivism - Identity - Self-Help System - Politics - Power

\section{INTRODUCTION}

Especially after the rise of structural realism, first presented by Kenneth Waltz's (1979) Theory of International Politics, as a mainstream theory in the field of International Relations (IR), much of theoretical development has been continually done around the question whether international system is anarchic or not, and how states are expected to behave under such an environment. Neorealists have argued that anarchy begets the self-help system while neoliberals have affirmed that, although states do behaviour in a self-interestedly and competitive manner, that does not preclude co-operation.

In an attempt to overcome the assumption of the self-help system as natural institution of anarchy, Alexander Wendt blew a fresh air into IR theoretical debate with his famous article Anarchy is what States Make of it: The Social Construction of Power Politics, published in 1992. Wendt (1992) introduced his view of constructivism, a social theory of international politics according to which states identities and interests are a product of the process of their socialisation. His main critique of neorealists and neoliberals is their assumption that, since identities and interests are exogenous to states, they cannot escape the self-help system under

\footnotetext{
${ }^{1}$ Mestrando em Relações Internacionais pelo Programa de Pós-Graduação em Relações Internacionais San Tiago Dantas (Unesp/Unicamp/PUC-SP). E-mail para contato: g.alvesneto3@gmail.com.
} 
anarchy. Hence, Wendt (1992) asserts that states have multiple identities which exist only within a social context and that these identities are not naturally defined a priori, but emerge only through their interaction, i.e. when ego encounters alter. In constructivism, states have more power of agency to define their interests and to create more altruistic identities. That assumption led Wendt (1994) to demonstrate how a collective identity of states could be formed, i.e. the identity of the Self would include the Other, and an international state would arise. Through the change of identities, states could overcome self-interested behaviour and the anarchic structure would no longer be characterised by the self-help system.

Wendt's work was a breakthrough in IR theory and since then it has been a very influential contribution to further debate in the discipline. Mercer (1995) was one of the first scholars to criticise Wendt by applying the Social Identity Theory (SIT), developed by the psychologists Henri Tafjel and John Turner in the 1970s in order to explain the findings in minimal-group paradigm experiments. As the author defines it, SIT is a "social psychological theory of intergroup behavior" [sic] (MERCER, 1995: 238), whose analysis concern the group rather than the individual level of identity formation. While not denying that group configurations and therefore identities and interests may change, Mercer (1995) disagrees with Wendt's conclusions, i.e. that a system other than self-help is possible. Both the social and psychological turn created a flourishing environment for further development in IR theory that put into the question the neorealist capacity to explain the international system, especially after the end of Cold War and the rise of the United States as the only superpower. In response to these critiques, Waltz published an article in 2000 where he claims his theory is still valid for the understanding of international relations. For him, the end of bipolarity brought a change in the system, but not a change of the system. "International politics remains a self-help arena", so he argues. (WALTZ, 2000: 5).

To answer the question whether another system other than self-help is possible is the main objective of this article. While I do not disagree with Wendt's assumption that identities and interests are socially constructed by actors in their interaction process, thus giving states agency to change them, I do affirm that the scope for systemic change is limited. What are then the limits of the systemic change as proposed by Wendt? My hypothesis is that politics limits the capacity states have to overcome self-interested behaviour. I argue that political entities no matter how they are organised - identify themselves through the differentiation of others, i.e. Self cannot include the Other. The interaction among political entities imply in power relations, and according to the Schmittian concept of political, there must be always the possibility of a conflict through the recognition of enmity. This argument is built on the 
assumption that politics is inherent to socialised people and, therefore, it does not concern the debate whether the human nature, on an individual level, is good or evil.

In addition to this introduction, this article will include four sections. In the first section, I analyse the conception of collective identities as according to Wendt $(1992,1994)$ and Mercer (1995), and expect to identify the blind spot in the hypothesis of Wendt's social theory. In the second section, I briefly discuss Aristotelian and Kantian philosophy on the social and political man. I intend thereby to shed light on the premise of this article: socialised people have the tendency to form a political entity. In the third section, I define the concepts of politics and power as according to Stoppino (1998), Bobbio (1998) and Schmitt (2007). By revisiting Schmitt's Concept of the Political, I hope to contribute to a deeper understanding of his friendenemy category, where I claim he is also concerned with the dimension of identity in politics and posits arguments that dialogues with the constructivist theory of Wendt. In the fourth section, I intend to show how the assumptions discussed in the previous sections affect the understanding of international relations and the self-help system. I argue that, as a matter of fact, the question of whether international system is anarchic or not has little to do with states behaviours. I also state that, by assuming the self-help system as a feature of political and power relations, IR scholars can overcome the debate around the Westphalian state, which I believe to be more an empirical rather than a theoretical issue. In my conclusions, I shall affirm that as long as people live in society, they have the tendency to be political beings. And as long as they are political beings, the friend-enemy relations will endure. Therefore, the potentiality of a conflict between two political entities precludes the transformation of a self-help system into a collective identity.

\section{COLLECTIVE IDENTIY FORMATION AND SOCIAL IDENTITY THEORY}

The constructivism theory, as proposed by Wendt (1992), intended to challenge rationalism in IR. In rationalism, the focus is on the behaviour of states in an exogenous and given structure characterized by the self-help system. That means that, although neorealists and neoliberals disagree whether cooperation under an anarchic system is possible or not, both regard states as the primary actors in that system and define security in self-interested terms. As himself claims, constructivism is a "fully socialised" in comparison to the "undersocialised" systemic theory in rationalism (WENDT, 1992: 403).

Wendt defines constructivism "as [a] form of social construction of subjectivity, which concerns on identities and interests-formation" (WENDT, 1992: 393). Through this "social turn" in IR theory, the author sheds light on the process of interaction among states and what 
that means for their identities and interests' formation. Therefore, how states behave has less to do with the structure than with the sociological process. By assuming that, states in Wendt's theory have more agency for shaping the international system. Accordingly, "[s]elf-help and power politics are institutions, not essential features of anarchy. Anarchy is what states make of it." (WENDT, 1992: 395). Three conclusions can follow from Wendt's analysis: 1) states are still the primary actors in international system; 2) Wendt does not deny anarchy, but affirms that it only facilitates self-interested behaviour; and 3) anarchy need not be characterised by self-interested states which act in a self-help system in terms of security.

But how can states overcome self-help system? The key for Wendt (1992) is to reconstruct states' identities. This would be possible through a change in the way states interact, e.g. through institutionalisation. Assuming that social threats are socially constructed, and thus not naturally given by the structure, Wendt (1992) asserts that creating positive expectations via cooperation would suffice to lead states to give up on an egoistic behaviour and act more altruistically and "prosocially". By reconstructing states' interests, states would create a collective identity. Wendt's constructivism focuses primarily on the process of interaction. The more states co-operate, the more they will be inclined to continue the co-operation and expect others to co-operate as well. States would seek absolute gains and not relative gains, as in the realist theory. But differently from the neoliberal theory, Wendt (1992) explains absolute gains by the creation of a collective identity and not constrained by institutions.

How the process of a continuous co-operation in states' interaction would work is illustrated by Wendt with an analogy of ego and alter first encounter:

Consider two actors-ego and alter-encountering each other for the first time. Each wants to survive and has certain material capabilities, but neither actor has biological or domestic imperatives for power, glory, or conquest (still bracketed), and there is no history of security or insecurity between the two. What should they do? Realists would probably argue that each should act on the basis of worst-case assumptions about the other's intentions, justifying such an attitude as prudent in view of the possibility of death from making a mistake. Such a possibility always exists, even in civil society; however, society would be impossible if people made decisions purely on the basis of worst-case possibilities. Instead, most decisions are and should be made on the basis of probabilities, and these are produced by interaction, by what actors do. In the beginning is ego's gesture, which may consist, for example, of an advance, a retreat, a brandishing of arms, a laying down of arms, or an attack. For ego, this gesture represents the basis on which it is prepared to respond to alter. This basis is unknown to alter, however, and so it must make an inference or "attribution" about ego's intentions and, in particular, given that this is anarchy, about whether ego is a threat [...] ego makes a new gesture, again signifying the basis on which it will respond to alter, and again alter responds, adding to the pool of knowledge each has about the other, and so on over time. The mechanism here is reinforcement; interaction rewards actors 
for holding certain ideas about each other and discourages them from holding other (WENDT, 1992: 404-405).

As one can see, the possibility of a collective identity depends on whether ego sees alter as his friend or enemy. And as Wendt (1992) affirms, enmity is not something that exists $a$ priori, but is rather socially constructed through the interaction of ego and alter. With this assumption, Wendt (1992: 397) asserts that "if the United States and Soviet Union decide that they are no longer enemies, 'the cold war is over'". Indeed, this is a compelling argument within constructivism, and one could say that it better explains the end of Cold War than Waltz's structuralist theory. However, two critiques follow the analogy presented above: 1) if cooperation needs to be continually reinforced - at least at the beginning - then Wendt must also assume that ego and alter could eventually not comply with it or that their actions can be misinterpreted; 2) Wendt himself claims that there is always the possibility of worst-cases scenarios that might include death.

Wendt (1992: 412) anticipated his critics by stating that "[ $t]$ he realist might concede that such systems are socially constructed and still argue that after the corresponding identities and interests have become institutionalized [sic], they are almost impossible to transform.". Mercer (1995) criticised Wendt (1992) by claiming that states cannot escape self-help behaviour and will continue to seek relative gains. His article is also based on constructivist assumption in relation to states' identities. But he analyses it through the lenses of SIT, providing a social psychological analysis of how differentiation between groups account for a cognitive bias in social interaction and the ever-probability of conflicts. Therefore, the reason why states seek relative gains is a desire for positive self-image, which leads to competition. The desire for a positive self-image echoes Aron (2003), where he asserts that objectives of states foreign policy are power, glory and idea. By using examples of psychological experiments, Mercer (1995) illustrates that the stronger in-group identity is, the more this group will differentiate itself from others and seek for relative gains by comparison with other groups.

Mercer (1995) asserts that the question about states interaction is not whether they can co-operate or not, but whether if this co-operation can overcome egoistic incentives (MERCER, 1995: 234). And, still according to him, to assume that the first encounter of ego and alter would be harmonious is not better than to assume a potential conflict. But it does not mean that intergroup differentiation necessarily leads to extreme cases. As he exemplifies through this article, psychological experiments have shown that

[...] subjects consistently favored [sic] the in-group and tried to maximize the difference in scores between the in-group and the out-group. The evidence also indicated that the subjects also wished to be fair and, therefore, this 
discrimination was not as extreme as it might have been. [...] 'Beating the outgroup is more important than sheer profit.' Because even the most minimal categorization led to intergroup competition, Tajfel and Turner concluded that "we are dealing here with some factor or process inherent in the intergroup situation itself" (MERCER, 1995: 240)

It is important to make it clear that SIT works with the identity on the group level and not on the individual level. According to this assumption, one's identity is partially defined by their social identity. Hence, there is a universal desire for self-esteem and a positive self-identity that is achieved through the intergroup comparison. The more a group maximise the difference with others, the greater this self-esteem will be.

Two examples help illustrate this hypothesis. The first one is nationalism and xenophobia. Nationalism is strongly built on the differentiation between citizens of a specific country and foreigners. The more one identifies with their nationality, the more they will differentiate themselves in comparison to other nationalities. A too extreme identification through differentiation leads to xenophobia. The second example is in sports fans to be found. Football fans identify themselves by grouping according to their favourite clubs. Whatever their nationality, language, ethnicity is, they all form an in-group identity and hope their clubs will do better than the others. Therefore, an individual may have as many identities as the number of different groups they are socialised in, like Wendt (1992) has claimed.

The abovementioned examples do not claim that on the individual level an altruistic behaviour or the inclusion of alter in ego's identity definition is impossible. But one's identity is partially defined by their social life, and groups identification are inherently competitive. Alike Wendt, Mercer (1995) also claims that identities may change and that group boundaries are not fixed. But, for him, groups will always be egoistic. An enlargement of states identity, like the European Union, necessarily includes the differentiation between those states and others. Assuming this makes it almost impossible to imagine the realisation of an international state which will overcome the self-help system as posited by Wendt (1994). As Mercers (1995: 250-251) states: "Unless the group encompasses all of humanity - and this is improbable at least in part because group cohesiveness decreases as it becomes more abstract - humans will always form groups."

The eternal competition between ego and alter in Mercer's theory echoes Morgenthau's assumption of the human nature as the main cause of international conflict. But while the classical realist claims human nature is always willing to maximize power, SIT argues only that groups - and not individuals - are inherently competitive and egoistic. Whether this competition will result in a conflict or co-operation, is a social construction. 
My critique of Wendt's constructivism, is partially explained by SIT. However, I posit that the egoistic behaviours are inherent to social-political collective identities, and not necessarily a social-psychological characteristic. Moreover, not all intergroup interaction follows a political relation. In that sense, my hypothesis differs from classical and structural realism - since the impossibility to overcome the self-help system rest neither on human nature nor on the presumed anarchic structure, respectively - and also expands the argument provided by Mercer (1995) through SIT. I argue that the possibility to create an entirely collective identity and to achieve an "international state", as suggested by Wendt (1994), can only be realised if one declines politics and power relations, especially the Schmittian concept of political. Wendt's blind spot is not mentioning that these social interactions are also political. Ego and alter would not have a competitive interaction only if they were not political entities - since this presupposes a friend-enemy relation - that means that the self-help system, or the egoistic behaviour of actors, will endure as long as politics exist. Before this conception of politics is further discussed, I shall briefly examine Aristotelian and Kantian philosophy on human sociability and politics. I hope thereby to identify some key elements that will help support my argument that humans are naturally inclined to live in communities that may form also political identities.

\section{SOCIAL PEOPLE, POLITICAL PEOPLE}

In his famous work Politics, Aristotle is concerned with human affairs in the Polis (City). The philosopher stated that people are by nature political animals. By people's capacity for speech, they can distinguish between good and bad, just and unjust. Bearing this in mind, another important concept used by Aristotle is the concept of telos: the purpose of something. For Aristotle, the telos of human beings is to be happy and have a virtuous life. And only by living a public life in a political community, human beings can fulfil their telos. Through the Aristotelian perspective, politics can thus be seen as a means through which human beings achieve their natural goal. But a deeper - yet brief - analysis of his philosophy can enhance one's understanding of the meaning of politics according to him.

In his analysis of Aristotle's work, Edward Clayton highlights that the Polis is something natural and not merely an institution created by people. That derives from the fact that the very beginning of the Polis formation - partnerships to create a family, which would later become a village and thereafter a proper city - is driven by natural impulses. It can be assessed from that perspective that the political life is inherent to human social life. Every Polis is a political community through which a socialised life may lead people to live a happy life. 
But as Clayton points out, people have the power to decide whether they will pursue a happy, virtuous life, as well as decide between good and bad, just and unjust. Therefore, the importance for Aristotle's philosophy the capacity of speech. A political life is the act of discussing and deciding which goals are to be pursued. The question whether individuals are inherently egoistic or altruistic in Aristotelian philosophy has been continually debated, as Bortolozzo (2010) has stressed. But it is sufficient to keep in mind the concept of the political man, in the sense that humans can only fully realise their existence within a society. Besides Aristotelian, Kantian philosophy can help expand the understanding of naturally socialised and politicised human beings.

To the purpose of this article, the main aspect of Kantian philosophy is the concept of "unsocial sociability" and what does that imply to Kant's perspective of politics. As Klein (2013) points out, Kant explains through that concept that humans have at the same time the inclination to socialise and the propensity to isolate. These two human characteristics are mutually constituted and given by Nature. Through the correlation of these two inclinations of human nature, harmony can be constituted. Similar to Aristotle, Kant believes that only in society human beings can live as such. Klein (2013) asserts that the understanding of the concept of "unsocial sociability" must be done through a biological-teleological perspective, i.e. a socialised life is inherent to human nature as well as something instrumental to achieve the goals of human beings.

The unsociability of human nature means that every man has a tendency to exercise his will against others, while, at the same time, they do not want to submit their own will to others (KLEIN, 2013). That tendency to isolation is what makes the existence of some kind of authority for they to obey necessary. This authority explains the role of politics in Kantian philosophy. According to Lebrun (1992), although Kant and Hobbes have different anthropological perspectives, both of them apply the same model of a political organisation for the constitution of a civic society. This constitution of a civic society can be illustrated under the Kantian concept of Dominius originarius: political power is to be understood as what creates the citizens, and not merely as means of rule.

The two philosophical approaches discussed in this section do not really give a clear definition whether human beings are inherently egoistic or altruistic. And nor is the objective of this article to define it. However, both Aristotelian and Kantian philosophies support the argument that human beings have the inclination to live in societies, which is intrinsically related to the formation of a political community, in that one can also affirm: collective identities have the tendency to be also political identities. The words "inclination" and "have 
the tendency to" have been italicised in order to highlight the sense of potentiality they express. They neither mean that individuals must socialise nor that every collective identity, our group of individuals, is also a political community. This remark is important for the arguments presented in the next sections. The following section will discuss the modern concept of politics and political power as according to Schmitt (2007), Stoppino (1998) and Bobbio (1998). What differentiates a political community and other groups or collective identities?

\section{POLITICS AND POWER: A SCHMITTIAN VIEW}

In his work The Concept of the Political, Schmitt seeks to give a clear and specific definition of the political realm that distinguishes it from others, such as economics, law, morality, aesthetic and so on. Hence, Schmitt (2007) claims that the definition of political is in the antithesis friend-enemy to be found, in the same way that morality defines itself by the good-evil antithesis and aesthetic by the distinction between ugly and beautiful. By affirming that, Schmitt (2007) assumes that the political realm is independent from other concepts. Therefore, Schmitt (2007) also criticises the equation state $=$ politics. For him, this assumption is erroneous and leads to the misconception of what the real meaning of the political is. The modern state merely possesses the monopoly on politics, but is not its equivalent.

From these two considerations - 1) the political realm is independent from any other; 2) the state is not the same as politics but rather an institution with the monopoly on politics - two other conclusions can be drawn: 1) the independency of the political realm helps explain why a state would wage war against another state even if that meant material and economic losses; 2) the end of the modern state will not mean the end of politics. The political has existed long before the state - e.g. in Greek Polis - and will exist in whichever political entity rises in the aftermath of modern state's erosion.

Although Schmitt (2007) does not focus on the word identity in the same way as Wendt (1992, 1994) does, the antithesis friend-enemy is naturally realised within the concept of identity. It can be seen through the distinction of ego and alter; the Self and the Other, who is a stranger, whose identity is essentially different from the Self. But the Schmittian view of enemy does not presuppose an endless and a priori conflict between ego and alter like in a Hobbesian state of nature. Nevertheless, there is always the possibility of a conflict in extreme cases. This potential conflict can also be read through Kantian lenses. As Borges (2015) explains, Kant distinguishes inclinations from passion, in which the first is "a habitual sensuous desire', and passion is the 'inclination which can hardly, or not at all, be controlled by reason' (Ant 7:251 apud BORGES, 2015: 337). Expressed in other words, extreme cases 
occur when a political entity cannot hinder its passions through its reason. The Kantian concept of "unsocial sociability" would suffice to explain why, even without a single legitimate and sovereign authority in the international arena, states are not continually engaged in conflicts against one another: the potential of conflict is an inclination attributed to the unsociability that needs not mean a passionate action of actors. But unlike Kant, Schmitt (2007) asserts that the decision of conflict is a political decision that has no correlation with morality.

Another important remark to make on the concept of enmity for Schmitt is that it exists only within a collective identity differentiation from another. As he points out: " $[\mathrm{t}]$ he enemy is solely the public enemy [...] is hostis, not inimicus in the broader sense." (SCHMITT, 2007: 32). By distinguishing that, the Schmittian concept of the political works with the group level and not with individuals. A political enemy does not imply in individual hatred. The enemy is also not just an economic competitor. The existence of political enemy is thus independent from any other division. Its uttermost differentiation is the potential of a conflict.

Consequently, if it is assumed that the state has the monopoly on politics, and that the distinction of who is friend and who is enemy is a decision within the political realm, so it is right to affirm that the modern state is the political entity which legitimately decides itself on friendship or enmity relations. If other collective identities claim the power to define the enemy, then is the political authority of the state contested and it has no longer the monopoly on politics. Another conclusion can be drawn from that assumption. So-called religious, ethnic, nationalistic and other types of conflicts are also necessarily a political conflict. A conflict cannot exist outside the political realm. Religion, ethnicity and nationalism can help intensify the political conflict, e.g. extreme nationalism. That suffices to affirm that a collective identity - nationalism as one of the best examples within the modern state system - is not inherently identified to the definition of enmity. The division of states according to a national-citizenship does not alone drive to conflicts between nations. Thus, the end of national states is also not sufficient to end international conflict.

Notwithstanding the fact that Schmitt wrote the first edition of the Concept of the Political seventy years before Wendt published his article about the social construction of anarchy, their works clearly have a theoretical dialogue, explaining why Wendt might have overseen some aspects of Schmittian view of politics while producing his theory. Schmitt too asserts that states identities are not immutable: "[ $\mathrm{t}]$ he criterion of the friend-and-enemy distinction in no way implies that one particular nation must forever be the friend or enemy of another specific nation or that a state of neutrality is not possible or could not be politically reasonable.” (SCHMITT, 2007: 34). Without explicitly stating it, Schmitt considers states 
identities as socially constructed and not given a priori as much as Wendt does. But the biggest issue for understanding why the Schmittian view of politics limits the possibility to overcome the self-help system follows from the below excerpt:

It is irrelevant here whether one rejects, accepts, or perhaps finds it an atavistic
remnant of barbaric times that nations continue to group themselves according
to friend and enemy, or hopes that the antithesis will one day vanish from the
world, or whether it is perhaps sound pedagogic reasoning to imagine that
enemies no longer exist at all. The concern here is neither with abstractions
nor with normative ideals, but with inherent reality and the real possibility of
such a distinction. One may or may not share these hopes and pedagogic
ideals. But, rationally speaking, it cannot be denied that nations continue to
group themselves according to the friend and enemy antithesis, that the
distinction still remains actual today, and that this is an ever present [sic]
possibility for every people existing in the political sphere.[...] A world in
which the possibility of war is utterly eliminated, a completely pacified globe,
would be a world without the distinction of friend and enemy and hence a
world without politics. It is conceivable that such a world might contain many
very interesting antitheses and contrasts, competitions and intrigues of every
kind, but there would not be a meaningful antithesis whereby men could be
required to sacrifice life, authorized to shed blood, and kill other human
beings. For the definition of the political, it is here even irrelevant whether
such a world without politics is desirable as an ideal situation. (SCHMITT,
2007: 28-35).

The Schmittian enemy can only exist within its antithesis friend. Were there no enemies, there would also be no politics. Accordingly, a political entity presupposes another political entity existing as an enemy through their coexistence. An entire political identity that embraces all humanity is thus not possible, as he affirms: "[t]he political world is a pluriverse, not a universe." (SCHMITT, 2007:53). That does not mean states - or whichever other political entities there might be - are always engaged in wars. Although "war follows from enmity" (SCHMITT, 2007: 32), the existence of enemies is not realised by wars. The political realm presupposes the possibility of enmity in order for its concept to remain valid. This is what Raymond Aron would later echo by affirming that states interact "in the shadow of war" in his Peace and War: A Theory of International Relations.

Besides the Schmittian definition of the political concept, Bobbio (1998) and Stoppino (1998) also discuss politics and the concept of power, which are intrinsically connected and limit the possibility of overcome egoism within interactions of political entities. Stoppino (1998) refers to politics in an Aristotelian approach as everything that concerns the Polis (City), i.e. everything that is public, socialised or sociable. According to the author, the concept of power is inherently correlated with politics. Unlike economic or ideological power, political power refers to the power of a man over another man, in which one tries to enforce their will 
against other's will and thereby determines the behaviour of the other. Thus, power is always a relative concept. Power cannot exist in vacuum. It is always expressed by the relation between two or more identities. As he states, "man is at the same time subject and object of social Power." (STOPPINO, 1998: 933).

The specific element of political power, according to Stoppino (1998), is the possession of instruments of coercion and the prerogative to use physical force through these instruments. However, this does not mean that political power needs necessarily to carry out actual physical force, but only that it may be used if need be. By analogy with Economics, it could be said that the use of force is the "lender of last resort" of political power. This is why Stoppino (1998) differentiates actual power and potential power. Potential power is well explained by Lebrun (1992: 10) as "the capacity to execute a specified action, even though the agent never carries out this action" but that can come into being at any time.

In the same way as Schmitt (2007), Bobbio (1998) defines as political authority the group who has the power to decide to use fore in extreme cases. But Bobbio (1998) claims that even though the use of force is a necessary condition of political power, it is not sufficient for it to exist. Although other groups may decide to carry out physical force, even continually, he affirms that they cannot be delineated as a political power. For him, political power is characteristic by its exclusivity (the tendency to not allow other independent armed groups within its domain), universality (the capacity a group has to make legitimate decisions on behalf of the entire community), and inclusivity (the possibility to imperatively intervene in any other activity of the group, e.g. economy).

Another important contribution on Bobbio's analysis of the modern concept of politics is that it does not follow Aristotle, who believes politics has a teleological attribute to human beings. Instead, Bobbio (1998) affirms that politics can have as many objectives as a political group needs in different times and circumstances. Politics is an end in itself. The most important remark Bobbio (1998) makes that is also useful for the purpose of this article, is to differentiate the collective level from the individual level. By evoking the Weberian concepts of ethics of conviction and ethics of responsibility, Bobbio (1998) differentiates the ethical debate on the individual and on the group level as political entity, respectively. Thereby, what is morally imperative for the individual, may not be politically mandatory for the group in which that individual takes part. In that sense, this statement is similar to the hypothesis according to SIT that the interest of a group may not be of best interest of the individual part of this groups.

But what do the abovementioned definitions of politics and the relational dimension of power mean to the understanding of international relations and the international system? Is it 
possible to affirm that states interact under anarchy? Even if the system really is anarchic, does it matter for the explanation of states behaviour? Would the end of so-called Westphalian State change the way intergroup politics work? Most of all, can political entities overcome self-help system? Without attempting to give exhaustive and final answers to these questions, next section will discuss them and intends to shed light on Wendt's blind spot: the limits of social reconstruction of power politics.

\section{BEYOND ANARCHY: THE EGOISM OF POLITICAL COLLECTIVE IDENTITIES}

The discussion suggested in this section will be concerned with the three conclusions drawn from Wendt $(1992,1994)$, which were exposed in the first section: 1) states are the primary actors in international system; 2) Wendt (1992: 396) does not deny anarchy, but affirms that it "plays only a permissive role"; 3) anarchy need not be characterised by self-interested states which act in a self-help system in terms of security. Self-interested identities are an institution of anarchy socially constructed by states interaction, and not a given structure exogenous to states. Analysing the two first points is necessary for the answer of the main question of this article, related to the third conclusion provided by Wendt: can states overcome the self-help system?

As already stated in this article, Wendt (1992, 1994) continues the approach of neorealists and neoliberals considering states as the most important actors in international system - although not the only ones. Playing the role of a bridge between mainstream positivist and post-positivists epistemologies, his constructivism differs from other - sometimes considered more radical - perspectives and theories of IR such as post-modernism and postcolonialism, as well as other constructivist theorists. One could say that, albeit his sociological approach of the system was a real breakthrough in IR theory, he played it safe. This is a starting point for Wendt $(1992,1994)$ to oversee the limitations of his theory. He too considered the Westphalian State as a fact in international relations. To affirm that defined states territories that are sovereignly secured by international consensus of each state's sovereignty is a socially constructed institution does not contradict the understanding of the existence of the so-called Westphalian State, and paves the way for imagining a more altruistic system through the erosion of these institutions.

Mostly in the aftermath of Cold War, the expansion of economic neoliberalism and a more complex and interdependence between states fostered the role played by economics, international markets, and other institutions as presumably new agents in the international 
arena. This scenario was observed by scholars who astonishingly claimed that the Westphalian Peace is a myth and announced the advent of a New Medievalism in a post-international order characterised by an overlapping authority and loyalty between socio-political identities, nationstates sovereignty and transnational market (OSIANDER, 2001; FRIEDRICHS, 2001). However, saying that Westphalia Peace is entirely a myth, or claiming the erosion of the modern system of states, risks ignoring the fundamental understanding of the modern organisation in international relations or, in the other end of this continuum, taking for granted the existence of a true Westphalian State that is now coming to an end.

Krasner (1995) provides a more accurate and liberating analysis of this issue. Unlike Osiander (2001), he recognises the Westphalian System as merely a historical point of reference for theoretical development. There has never been a truly Westphalian State which is completely sovereign and autonomous within its territory and political decisions. There is though some states which have more capacity to preserve their autonomy - and therefore are closer to an ideal Westphalian State - than others. But compromises of the "ideal" Westphalian State have always occurred - be it through convention, contractors, coercion or imposition, according to the author. One could say that there is a growing interdependence between states and that they are further from the autonomy than before, but to say states have ever been truly autonomous and sovereign is erroneous. States capacities to completely formulate their policies independently from others are different. As Krasner (1995: 117) asserts: "All states are not the same. Some have closely approximated the Westphalian model. Others not."

According to the assumptions of politics in the previous section, the modern state is merely one type of political entity, defined by nationality and territoriality, that is the authority recognised by other actors in the international arena that possesses the monopoly of politics within its territory and population. The existence of politics beyond the concept of the state indicates that politics has existed prior to the Westphalia Peace and may continue to exist in a future form of political organisation. Therefore, the modern nation state system is not a variable to determine why states behaviour under a self-help system. At most, this kind of political entity impacts the way competition develops, in which extreme nationalism may lead to a more intensive conflict. Now, the understanding of the system as anarchic will be discussed.

Wendt $(1992$, 1994) regards international system as anarchic alike neorealists and neoliberals. Certainly, in a juridical-formal perspective, there is no authority in the international arena above states sovereignty - although the United Nations of Security Council could be seen as an institution that almost classify as such in security terms. However, in political and substantively aspects, it makes more sense to speak of a hierarchic system constituted by power 
relations. In the four instruments, as explained by Krasner (1995), through which states sovereignty may be compromised - convention, contractors, coercion or imposition - power relations are an essential aspect of their composition. According to the definition provided by Stoppino (1998), power is always a relational thing in which an actor A tries to persuade actor $\mathrm{B}$ to act like A wants him to act. Even if this is done unconsciously by A, or if B believes it is acting for his best, while in fact it has been manipulated by $\mathrm{A}$, this is a power relation in which A has more power than B. From that assumption, the following hypothesis could be drawn: a political entity is the more powerful the greater its scope for political actions and decisions is. There is a tendency to expand its power. Nevertheless, as Onuf and Klink (1989: 150) have pointed out: "[t]here are limits wherever there is politics". Thus, there will eventually be an area of conflict of interests with another political entity. The less A needs to threat to use or to really deploy its capabilities in order to convince B to behave like it otherwise would not do, and B accept the imposition of A's interests, the more powerful A can be considered in relation to B. That is the reason why it is important to distinguish between the potential power - the realm of capabilities which can be deployed in any time but are not still used - and actual power - the amount of the potential power which is being deployed.

If political power can only be realised within a political relation, the existence of a political power presupposes at least another one. There can be no power without an antagonistic power. Therefore, power relations imply in hierarchy. It is possible to affirm that in the international system there is a plurality of political authorities which strive to establish their interests towards other authorities through a hierarchical system. This is different from anarchy, above all a Hobbesian anarchy. Another concept of Stoppino (1998) provides a better understanding of hierarchic relations: stabilised power.

Power is stabilised when there is a high probability that B will continuously behave according to the interests of $\mathrm{A}$, and also that $\mathrm{A}$ is likely to continue executing its power in relations to $\mathrm{B}$. That scenario is then characterised by a rule-obedience relation. This may or may not be instrumentalised through an administrative apparatus. In that sense, it could be argued that since international system includes so many political authorities, power is less stabilised than in comparison with domestic politics - at least in states whose political authority is not strongly contested as in other states. In the international arena, it is not ease to rule incontestably over other political entities. However, some rule while others are ruled. That is why there is no Hobbesian state of nature in international relations.

Similarly, Onuf e Klink (1989) argue that it is not necessary to rule by the enforcement of formal-juridical instruments. Norms may be institutionalised merely through the process of 
ruling. They propose the distinction between three types of rule which overlap in international relations: hierarchy, hegemony and heteronomy - a Kantian concept the opposes autonomy by obscuring the lack of it. Whether scholars view the international system as hierarchic, hegemonic or heteronymic is not the point here. Suffices to affirm that international relations are characterised by asymmetric power relations which may appear in different forms and degrees - and therefore is not a concept exclusive of material capabilities - defined by social structures and processes (BARNETT; DUVALL, 2005).

An anarchic environment, according to the Hobbesian view, would be a pre-politicised society. If it is assumed that the international system is anarchic, then it would mean that states are also non-politicised entities. But unlike Waltz's anarchy as a coercive structure, and Wendt's anarchy as only a permissive environment for self-help behaviour, it is argued here that whether the system is anarchic or not has no implications for states behaviour. This assumption goes beyond the agent-structure dilemma and focuses on the relations between states, which are essentially political relations.

If states are political entities, then the interact with each other through, inter alia, political relations. That means that states interactions are developed under the shadow of a friend-enemy relationship. As identities may change, so the recognition of one state as a friend or enemy may also change. But the potential enmity endures if the political realm is to survive. If the analogy of ego and alter first encounter is used here as Wendt (1992) did, it can be stated that ego and alter would not have a competitive interaction only if they were not political.

According to the Schmittian concept of the political, the possibility to decide on the enmity must remain if the political concept is to endure. As he states:

The political entity presupposes the real existence of an enemy and therefore coexistence with another political entity. As long as a state exists, there will thus always be in the world more than just one state. A world state which embraces the entire globe and all of humanity cannot exist. The political world is a pluriverse, not a universe. (SCHMITT, 2007:53)

A collective identity that would create an international state as suggested by Wendt (1994) could therefore be created only if it were an apolitical entity. This is what makes it impossible for an everlasting collective identity of security exist. Individuals may not be always egoistic, but political identities are inherently self-interested. Accordingly, the scope for escaping the self-help system is limited.

\section{CONCLUSIONS}


The hypothesis developed by Wendt $(1992,1994)$ that, since states identities and interests are socially constructions, it is possible to overcome the self-help system under anarchy by the creation of an entire collective identity in which ego no longer sees alter as their enemy, was the object of this article. Although I agree with Wendt's view of a social construction of the world, which gave states agency to modify their identities and interest, I have argued that the scope for reconstruction of the institution of the self-help system is limited. My hypothesis is that these limits are inflicted neither by the structure nor by naturally egoistic characteristic of human beings, but are in the nature of politics and political relations to be found. I have claimed, therefore, that overseeing the role of politics between states was Wendt's blind spot while developing his theory.

This article was constructed in four sections in addition to the introduction and these conclusions. Firstly, Wendt $(1992,1994)$ and Mercer (1995) have been debated in order to highlight the mains aspects of the social construction according to Wendt, and the use of SIT by Mercer to analyse intergroup interaction and why groups seek relative gains towards others in order to achieve self-esteem. Secondly, Aristotelian and Kantian philosophies have been briefly discussed in an attempt to demonstrate the tendency of human beings to socialise and form political entities. The main aspects discussed was Aristotle's assertion that "man is a political animal" and Kantian concepts of "unsocial sociability". Thirdly, the Schmittian concept of the political as defined by the antithesis friend-enemy and the definition of politics and political power according to Bobbio (1998) and Stoppino (1998) have been analysed. Fourthly, it has been attempted to explain how the assumption of political relations imply in the theoretical view of the international system as anarchic or hierarchic, and how it affects the concept of self-help system.

By using the Schmittian concept of political it has been argued that the modern nation state is just one type of political identity that may exist. Once the concepts of state and political are distinguished, a theoretical analysis of states self-interestedly behaviour as result of to the Westphalian model cannot be applied. As Schmitt (2007) asserts, the form how a political entity is organised is not relevant to the essence of politics, i.e. the friend-enemy antithesis. It has also been argued the international system is hierarchic rather than anarchic, since power relations among states signify a complex net of rulers and ruled states. However, it has been claimed that this distinction does not really affects the self-help system. Therefore, the distinction of the political, in comparison to other spheres of human socialisation as the possibility of enmity, is a useful conceptual tool that sheds light on the essential characteristic of international relations that Wendt $(1992,1994)$ has overseen: politics are egoistic. 
If a world in which ego and alter do not have the potentiality of perceiving each other as enemies, and political entities co-operate truly altruistically is to exist, then this world will need to be apolitical. Furthermore, collective identities presuppose the differentiation of identities by comparison with other groups, as posited by SIT. The most important remark in this article has been to highlight a political analysis works on a collective/group level in spite of occupying itself with individuals.

Although the assumption of inherently egoistic political entities may be seen as too pessimistic and leaves no room for manoeuvre for a progressive development of international relations, it is worthy reminding two points: 1) Schmitt (2007) defines enmity as related to the ever-present possibility of combat, since politics must include the possibility of war. That does not mean that political relations must be always antagonistic or conflictual, as Bobbio (1998) affirms; 2) a pessimistic view of politics neither implies in the impossibility of co-operation among states, like neoliberals have already shown, nor that policy-makers should not seek cooperation and avoid conflicts.

Concluding, if Wendt $(1992,1994)$ really believes in the end of potential enmity between ego and alter, then they must be apolitical entities. If, instead, his theory aims to merely provide expectation for more co-operation between states, then Wendt has not developed much further from neo-institutionalist theories. However, if Wendt $(1992,1994)$ has a teleological conception of politics for a happy public life, then his hypothesis of an international state is an attempt to mirror Aristotelian Polis to modern politics. Ironically enough, Thucydides has long ago showed the conflicts between distinct political entities in Ancient Greece, in his "History of the Peloponnesian War".

\section{REFERENCES}

Aron, Raymond. 2003. Paz e Guerra entre as Nações. Brasília: UNB Press.

Barnett, Michael and Duvall, Raymond. 2005. 'Power in International Politics'. International Organization 59 (1): 39-75.

Bobbio Norberto. 1998. 'Política'. In Norberto Bobbio, Nicola Matteucci and Gianfranco Pasquino (eds), Dicionário de Política. Brasília: Editora Universidade de Brasília, pp. 954962.

Borges, Maria. 2014. 'Passions and Evil in Kant's Philosophy'. Manuscrito - Revista International de Filosofia 37 (2): 333-355

Bortolozzo, Lucas Dutra. 2010. Entre o Egoísmo e o Altruísmo: Um estudo sobre o conceito de amizade em Aristóteles. Master's Thesis, Instituto de Filosofia e Ciências Humanas da Universidade Federal do Rio Grande do Sul. 
Clayton, Edward. n.d. 'Aristotle: Politics'. Internet Encyclopedia of Philosophy [online]. n.d. At https://www.iep.utm.edu/aris-pol/\#H4 [Accessed on 30 January 2020].

Friedrichs, Jörg. 2001.'The Meaning of New Medievalism'. European Journal of International Relations 7 (4): 475-502.

Klein, Joel Thiago. 2013. 'A sociabilidade insociável e a antropologia kantiana'. Revista de Filosofia Aurora 25 (36): 265-285.

Krasner, Stephen. 1995. 'Compromising Westphalia'. International Security 20 (3): 115-151.

Lebrun, Gerárd. 1992. O que é Poder. São Paulo: Editora Brasiliense.

Mercer, Jonathan. 1995. 'Anarchy and Identity' International Organization 49 (2): 229-252.

Onuf, Nicholas and Frank F Klink. 1989. 'Anarchy, authority, rule'. International Studies

Quarterly 33 (2): 149-73

Osiander, Andreas. 2001. 'Sovereignty, International Relations, and the Westphalian Myth'. International Organization 55 (2): 251-287.

Schmitt, Carl. 2007. The Concept of the Political. Chicago: The University of Chicago Press

Stoppino, Mario. 1998. 'Poder'. In Norberto Bobbio, Nicola Matteucci and Gianfranco

Pasquino (eds), Dicionário de Política. Brasília: Editora Universidade de Brasília, pp. 933942.

Tucídides. 2001. História da Guerra do Peloponeso. Brasília: Editora Universidade de Brasília.

Waltz, Kenneth. 1979. Theory of International Politics. Menlo Park, California: AddisonWesley.

Waltz, Kenneth. 2000. 'Structural Realism after the Cold War'. International Security 25 (1): $5-41$.

Wendt, Alexander. 1992. 'Anarchy Is What States Make of It: The Social construction of Power Politics'. International Organization 46 (2): 391-425.

Wendt, Alexander. 1994. 'Collective Identity Formation and the International State'. The American Political Science Review 88 (2): 384-396. 